CRITICAL TERRAINS 



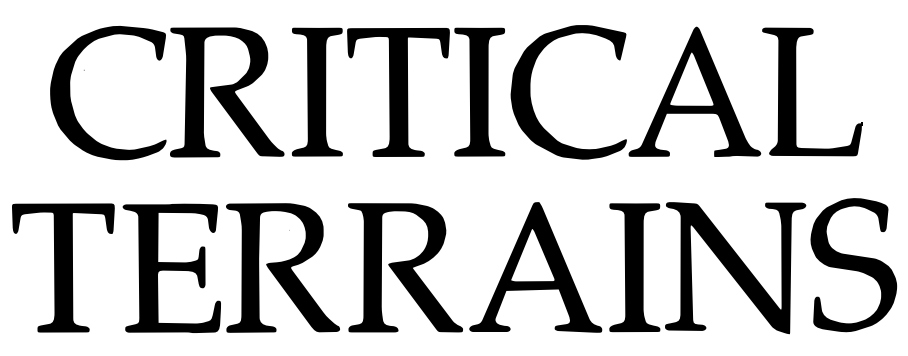

French and British Orientalisms

\section{LISA LOWE}

\section{Cornell University Press}

Ithaca and London 
Open access edition funded by the National Endowment for the Humanities/ Andrew W. Mellon Foundation Humanities Open Book Program.

\section{Copyright (C) 1991 by Cornell University}

All rights reserved. Except for brief quotations in a review, this book, or parts thereof, must not be reproduced in any form without permission in writing from the publisher. For information, address Cornell University Press, Sage House, 512 East State Street, Ithaca, New York 14850, or visit our website at cornellpress.cornell.edu.

First published 1991 by Cornell University Press

Library of Congress Cataloging-in-Publication Data

Lowe, Lisa.

Critical terrains : French and British orientalisms / Lisa Lowe. p. cm.

Includes bibliographical references and index.

ISBN-13: 978-0-8014-2579-0 (cloth) - ISBN-13: 978-0-8014-8195-6 (pbk.)

1. French literature - Oriental influences. 2. English literature-Oriental influences. 3. French-Travel-Orient-History. 4. British-TravelOrient-History. 5. Exoticism in literature. 6. Orient in literature. I. Title. PQ143.O75L6 1992

$840.9-\mathrm{dc} 20 \quad 91-55058$

The text of this book is licensed under a Creative Commons Attribution-NonCommercial-NoDerivatives 4.0 International License: https://creativecommons.org/licenses/by-nc-nd/4.0/

Cover illustration: Ingres, Odalisque with Slave. Walters Art Gallery, Baltimore. 
for Mei Lee Lowe

and Donald M. Lowe 
